\title{
An Empirical Reseaech of Various Factors Influencing Digital Access Towards HRM
}

\author{
Richa Priya, Vinita Sinha
}

\begin{abstract}
Abstract: Analytics is a domain which uses quantitative methods to organize, analyze and condense a massive amount of data. Synthesizing a large amount of data possessed by the organizations has been the focus of interest to enable informed decision making. The challenge of technologies used in HR is to identify data, which needs to be captured, modeled and predicted, to increase an organization's productivity. The present research intends to study the recent trends in perception of usage of technologies used by organizations in the area of HRM. The study also focuses on the willingness of an individual to participate in such organization. This study therefore uses TAM 3 model to examine the determinants for technology acceptance among users.
\end{abstract}

Key Words: Digital HRM, HR Analytics, Technologies in HRM, TMA3 Model

\section{INTRODUCTION}

The world has undergone a rapid growth in the area of information technology, which has led to digital dominance cultures and economies around the globe. Traditionally technology in HR were used administratively for payroll and record keeping, but with the evolvement of technology it is being used in every walk of HRM, like recruitment and retirement, training and promotion, levees and compensation [1]. By including the digital HR perspective, HR can focus on shaping the workforce and to support the organizational as this department collects data from within and outside organization [3]. Organizations have begun to realize the power of data possessed by them and are now keen to synthesize these data for informed decision making [4]. Therefore, the present piece of research work intends to study the behavior intension towards technologies in the area HR Analytics.

\section{LITERATUREREVIEW}

The term "HR Analytics" is being defined in different way by various researchers [5]. HRA can be defined as "the systematic identification and quantification of the people drivers of the business outcomes, with the purpose of making better and informed decision" [6]

HR Analytics is also known termed as talent analytics. It is combination of both data mining and business analytics

\section{Revised Manuscript Received on September 10, 2019.}

Richa Priya, Business analytics department, Symbiosis Centre for Management and Human Resource Development, Symbiosis International (Deemed), Pune, Maharshtra, India.

(Email: richa_priya@scmhrd.edu)

Vinita Sinha, Human resource department, Symbiosis Centre for Management and Human Resource Development, Symbiosis International (Deemed), Pune, Maharshtra,India.

(Email: vinita_sinha@scmhrd.edu) in every aspect of changes with reference to societies, growth and development [2]. Data is not new to HR domain

technique to human resource data [7]. The most important purpose of HR analytics is to identify the type of data [8], which should be taken into consideration and how to use this data to design model and predict, so that the organization gets best possible return on investment of human capital [9].

\section{a) E-HRM: -}

E-HRM is the electronic way of executing HR strategies, policies and practices in organization through a direct support of web-technology [10]. E-recruiting, e-learning, etraining etc. are some activities which are performed by EHRM that help the firm to meet their objectives [11]. EHRM provides not only easy access to the data but it also helps the organization to meaningfully arrange and preserve the high-quality data. Additionally, as E-HRM assists in organize and reorganize data, it also brings about more transparent working system [11].

\section{b) Artificial Intelligence and Machine Learning:}

The study of how to make computers do things that people are better at is known as Artificial intelligence (A.I.) [12]. Artificial intelligence is primarily based on symbolic computation to obtain meaningful information it not necessary that it would be just numbers [13]. Earlier research that using technology for HR purpose may have varied impact such as centralization and decentralization increased and decreased employee, efficacy and effectiveness [14] [15].

\section{c) Data Mining:}

Data mining refers to the process of identifying useful and valid patterns in data [16]. A previous study reveals that HRM constitutes important domain of data mining research that is dominated by method- and technology-oriented work [16] [17].

\section{d) HR in the cloud: -}

Cloud-based HR platforms are the next HR intervention. In today's world, every process is going the cloud way [18], therefore it is not expected from the people management to lag. While a few solutions are becoming popular by the day (Namely, Ultimate Software, Ceridian, ADP Vantage, Zenefits, Bamboo HR). Cloud based HR goes beyond user interface and engages employees with easy-to-use system that help people to be productive and happy at work [19]. Today's cloud-based HR solutions allows organizations to adapt cloud delivered HR best practices to their business processes, so that they can maintain their organizations

Published By. 
culture a brand value with the ability to personalize the look and feel, workflows and language [20].

\section{Theoretical background of TAM 3}

Tam model plays a significant role in the field of IT acceptance and its being used extensively in subsequent researches since its inception by [21]. Tam model has been applied and investigated earlier researches and it continues to be done by scholars. However, more and more researcher found faults in this model like exclusion of significant variables and made necessary amendments.

Traditional information system usually makes programmed decision for solving organizational problem through formal information processing [22]. However, analytics provide non-programmed decision-making capability and they are competent for solving problems through data knowledge of precedent (what happened), the present (what is happening) and for the future (what will happen). This requires combination of various technological approaches and bridge many technical areas including database, machine learning, and artificial intelligence. This study uses TAM 3 model to investigate analytics usage as TAM 3 is integrated model for determinants of perceived usefulness and perceived ease of use [23].

\section{Response Time}

Lesser response time is one of the success indicators of analytics. The faster the analytics response the more competent it is. Set of experiments were done by [24] [25] to determine the importance of response time.

\section{Task-Driven Dimension: -}

Task driven dimension are those dimensions which are dependent on the nature of job of the user, the output quality of the result, the response time of the system and the way the system explain the output.

\section{Technology driven dimension: -}

Technology- driven dimension are those dimensions which emphasize on the ease of use of technology and how the user is comfortable in using the digitized functions.

\section{Self- driven dimension: -}

Self- driven dimension are those dimensions which is totally user centric and it depends on the user comfort and object usability by the user.

Based on the literature, sub-factors have been identified to measure the independent variables -Perceived ease of use and perceived usefulness on the dependent variable Behavioral Intention for the usage of digital technologies in the human resource management.

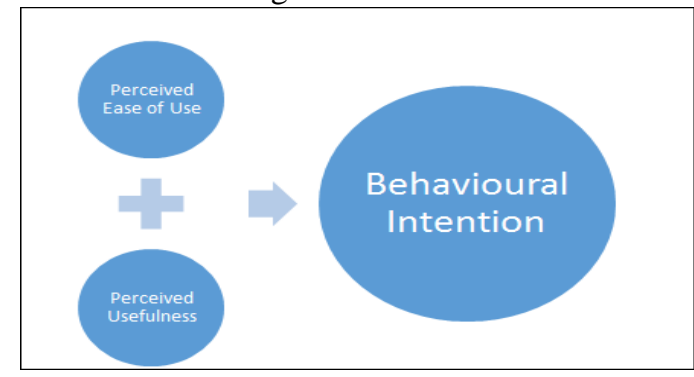

Fig.1. Proposed Model

\section{RESEARCH METHODOLOGY}

A. Objective:

1) To find out the relationship between perceived usefulness and the intention towards using the technology in HR.

2) To find out the relationship between perceived ease of use and intention towards using the technology in HR.

\section{B. Null Hypotheses}

H1:

There is significant positive relation between perceived usefulness and behavioral intention towards using the technology in HR.

\section{H2:}

There is significant positive relation between perceived ease of use and behavioral intention towards using the technology in HR.

\section{Methodology:}

Survey method was used for the current study. A questionnaire was developed for the same purpose. The items used in current study were derived from previous research and are modified slightly for the purpose of this research. This study was conducted with students who are doing a course in analytics and have been previously employed in an organization.

\section{Questionnaire development \& Data collection}

Questionnaire was developed using previous research papers. Questionnaire was physically distributed among the students. The major aim of the study was to find out the various factors which lead to adoption of digital technology in HRM. The study developed 43 survey questions based on existing, tested and verified instruments. The scales included the following: Job Satisfaction, Output quality, Result demonstrability, Response time, Computer Self -efficiency, Perception of external control, Computer anxiety, Object Usability, Perceived Enjoyment. Each item was measured by 3-4 item in the questions developed through existing literature. The questionnaire consisted of the following sections: demographic data including gender, age, and factors affecting behavioral intension to use the digital HRM. This laid the foundation for future research, so a sample of 50 was collected for the present study.

\section{E. Tools and technology}

The empirical data were analyzed by using linear regressions. Statistical Package for Social Science (SPSS) was used to analyze the hypotheses generated. Variables were measured by using a five-point Likert scales ranging from (1) strongly disagree to (5) strongly agree. The two independent variables taken were perceived ease of use and perceived usefulness and the dependent variable was behavioral intention of the user to use digital technologies in HR. 


\section{F. Results}

The descriptive table for the analysis showed that the mean and standard deviation for perceived ease of use are $=$ $3.57+0.63$ (Table 1). Similarly, mean and standard deviation for perceived usefulness are $=3.94+0.61$. The mean and standard deviation for the behavioral intention came out to be $=4.00 \pm 0.56$.

Table 1: Descriptive statistics for the study

Descriptive Statistics

\begin{tabular}{llll} 
& Mean & Std. Deviation & N \\
\hline BI Total & $\begin{array}{l}4.00000000000 \\
0001\end{array}$ & $\begin{array}{l}.563436169819 \\
011\end{array}$ & 50 \\
& & & \\
\hline PEU atotal & 3.5700 & .63294 & 50 \\
\hline PU Total & 3.9450 & .61089 & 50 \\
\hline
\end{tabular}

From the co-relations table it was found that co-relation between perceived ease of use and behavioral intention were $48.2 \%$ and the co-relation between perceived usefulness and behavioral intention was $58.8 \%$ (Table 2).

Table 2: Correlations

\begin{tabular}{ll|r|r|r}
\multicolumn{4}{c}{ Correlations } & \\
& & BI Total & PEU atotal & PU Total \\
\hline Pearson Correlation & Bl Total & 1.000 & .482 & .588 \\
\cline { 2 - 6 } & PEU atotal & .482 & 1.000 & .314 \\
\cline { 2 - 6 } & PU Total & .588 & .314 & 1.000 \\
\hline
\end{tabular}

SPSS allows us to specify multiple models in a single regression command. This tells us the number of the model being reported. From the model fit table, we come to know about the total no of models being reported for the data given. $\mathrm{R}$ is the square root of R-Squared and is the correlation between the observed and predicted values of dependent variable. For this study the value of $\mathrm{R}$ came out to be $0.666(66.6 \%)$.

$\mathrm{R}$ square gives the proportion of variance in the dependent variable which can be explained by the independent variables. This is an overall measure of the strength of association and does not reflect the extent to which any independent variable is associated with the dependent variable. The value for the $\mathrm{R}$ square for this study is $0.444(44.4 \%)$ (Table 3$)$.

Table 3: Modal summary of the study

\begin{tabular}{|c|c|c|c|c|c|c|}
\hline \multicolumn{7}{|c|}{ ANOVA } \\
\hline \multirow{2}{*}{\multicolumn{2}{|c|}{ Model }} & Sum of & & Mean & & \\
\hline & & Squares & df & Square & F & Sig. \\
\hline \multirow[t]{4}{*}{1} & Regressi & 6.902 & 2 & 3.451 & 18.74 & $.000^{\mathrm{b}}$ \\
\hline & on & & & & 4 & \\
\hline & Residual & 8.653 & 47 & .184 & & \\
\hline & Total & 15.556 & 49 & & & \\
\hline \multicolumn{7}{|c|}{ a. Dependent Variable: BI Total } \\
\hline \multicolumn{7}{|c|}{ b. Predictors: (Constant), PU Total, PEU atotal } \\
\hline
\end{tabular}

The ANOVA value for the research came out to be significant, and the F-value came out to be 18.74 (Table 4).

Table 4: ANOVA table for the study

\section{Model Summary}

\begin{tabular}{lllll} 
Model & R & R Square & $\begin{array}{l}\text { Adjusted } \\
\text { Square }\end{array}$ & $\begin{array}{c}\text { RStd. Error of } \\
\text { the Estimate }\end{array}$ \\
\hline $\mathbf{1}$ & $\mathbf{. 6 6 6}^{\mathrm{a}}$ & .444 & $\mathbf{. 4 2 0}$ & $\mathbf{. 4 2 9 0 8 7 3 1 4 9 4 4}$ \\
& & & & $\mathbf{8 3 8}$
\end{tabular}

\section{a. Predictors: (Constant), PU Total, PEU atotal}

\section{b. Dependent Variable: BI Total}

The coefficient table suggested that both perceived ease of use and the perceived usefulness are the good predictors for behavioral intention of the user using digital technology in HRM. The sig- values obtained were 0.006 for perceived ease of use and 0.000 for the perceived usefulness, which are lower than the p-values $(0.005)$. so, both perceived ease of use and perceived usefulness are significant (Table 5).

Table 5: Coefficients table for the study

\begin{tabular}{|c|c|c|c|c|c|c|c|}
\hline \multicolumn{8}{|c|}{ Coefficients ${ }^{\mathrm{a}}$} \\
\hline \multirow[b]{2}{*}{ Model } & \multicolumn{2}{|c|}{$\begin{array}{l}\text { Unstandardized } \\
\text { Coefficients }\end{array}$} & \multirow{2}{*}{$\begin{array}{l}\text { Standar } \\
\text { dized } \\
\text { Coeffic } \\
\text { ients } \\
\text { Beta }\end{array}$} & \multirow[b]{2}{*}{$\mathrm{t}$} & \multirow[b]{2}{*}{ Sig. } & \multicolumn{2}{|c|}{$\begin{array}{l}95.0 \% \\
\text { Confidence } \\
\text { Interval for B }\end{array}$} \\
\hline & B & $\begin{array}{l}\text { Std. } \\
\text { Error }\end{array}$ & & & & $\begin{array}{l}\text { Lower } \\
\text { Bound }\end{array}$ & $\begin{array}{l}\text { Upper } \\
\text { Bound }\end{array}$ \\
\hline $\begin{array}{ll}1 & \text { (Cons } \\
& \operatorname{tant})\end{array}$ & 1.189 & .464 & & $\begin{array}{l}2.56 \\
6\end{array}$ & .014 & .257 & 2.122 \\
\hline $\begin{array}{l}\text { PEU } \\
\text { atotal }\end{array}$ & .293 & .102 & .330 & $\begin{array}{l}2.87 \\
7\end{array}$ & .006 & .088 & .499 \\
\hline $\begin{array}{l}\text { PU } \\
\text { Total }\end{array}$ & .447 & .106 & .485 & $\begin{array}{l}4.22 \\
9\end{array}$ & .000 & .234 & .660 \\
\hline
\end{tabular}

So, the final regression equation obtained from the coefficient table is: $\mathrm{BI}=0.29(\mathrm{PEU})+0.45(\mathrm{PU})+1.19($ Table 5$)$.

We can therefore from our analysis conclude that we fail to reject our both the null hypothesis $(\mathrm{H} 1$ and $\mathrm{H} 2)$, and there is a significant relationship between perceived ease of use, perceived usefulness and behavioral intention.

\section{DISCUSSION \& RESULTS}

It is important for the companies to know how they can use HR data to make their strategic personal decisions. The selection of software is important as the software should match the operations of the organization. The appropriate software is not that difficult to find as leading software developer companies such as Oracle, IBM and SAP provide with standard packages, which can be customized as per the requirement. Smaller organizations which solely work for development for customized HR software's for organization also deliver best HR analytics software for various 
organizations. It is also equally significant that the people working in HR should be able to interpret the data. The organizations are now addressing this issue and have started to manage this kind of talent shortage by hiring Big Data Architect/ Analyst or data scientist to work in human resource department.

\section{LIMITATION AND FUTURE RESEARCH}

The study provides useful findings that behavioral intention to use technology in HR domain depends on the perceived ease of use of the technology by the user. It also suggests that the usage of technology in the HR domain also depends upon the perceived usefulness of the technology in the HR domain. Further studies can be done to find out the various factors that affect the behavioral intention of the user to use digital technologies in HR domain.

\section{REFERENCES}

1. Pemmaraju, S. (2007). Converting HR data to business intelligence. Employment Relations Today, 34(3), 13-16.

2. Voermans, M., \& van Veldhoven, M. J. P. M. (2007). Attitude towards E-HRM: an empirical study at Philips. Personnel Review, 36(6), 887-902.

3. Snell, S. A., Stueber, D., \& David, P. (2001). Follow Lepak. Virtual HR departments: getting out of the middle. Technical report, Ithaca, NY: Cornell University, School of Industrial and Labor Relations, Center for Advanced Human Resource Studies (CAHRS Working Paper\# 01-08).

4. George, L., \& Kamalanabhan, T. J. (2016). A study on the acceptance of HR analytics in organisations. International Journal of Innovative Research and Development, 5(2).

5. Bassi, L. (2011). Raging debates in HR analytics. People and Strategy, 34(2), 14.

6. Bondarouk, T., Ruël, H., \& van der Heijden, B. (2009). e-HRM effectiveness in a public sector organization: a multi-stakeholder perspective. The International Journal of Human Resource Management, 20(3), 578-590.

7. Madsen, D. Ø., \& Slåtten, K. (2017). The Rise of HR Analytics: A Preliminary Exploration. In Global Conference on Business and Finance Proceedings (Vol. 12, No. 1, pp. 148-159).

8. Othman, R., \& Teh, C. (2003). On developing the informated work place: HRM issues in Malaysia. Human Resource Management Review, 13(3), 393-406.

9. Angrave, D., Charlwood, A., Kirkpatrick, I., Lawrence, M., \& Stuart, M. (2016). HR and analytics: why HR is set to fail the big data challenge. Human Resource Management Journal, 26(1), 1-11.

10. Ruël, H., Bondarouk, T., \& Looise, J. K. (2004). EHRM: Innovation or irritation. An explorative empirical study in five large companies on web-based HRM. Management revue, 364-380.

11. Fındıklı, M. A., \& beyza Bayarçelik, E. (2015). Exploring the outcomes of Electronic Human Resource Management (E-HRM)?. Procedia-Social and Behavioral Sciences, 207, 424-431.

12. Rich, E. (1985). Artificial intelligence and the humanities. Computers and the Humanities, 19(2), 117 122.

13. Nemati, H. R., Steiger, D. M., Iyer, L. S., \& Herschel, R. T. (2002). Knowledge warehouse: an architectural integration of knowledge management, decision support, artificial intelligence and data warehousing. Decision Support Systems, 33(2), 143-161.
14. Tizhoosh, H. R. (2005, November). Opposition-based learning: a new scheme for machine intelligence. In International Conference on Computational Intelligence for Modelling, Control and Automation and International Conference on Intelligent Agents, Web Technologies and Internet Commerce (CIMCAIAWTIC'06) (Vol. 1, pp. 695-701). IEEE.

15. Jantan, H., Hamdan, A. R., \& Othman, Z. A. (2010). Human talent prediction in HRM using C4. 5 classification algorithm. International Journal on Computer Science and Engineering, 2(8), 2526-2534.

16. Strohmeier, S., \& Piazza, F. (2013). Domain driven data mining in human resource management: A review of current research. Expert Systems with Applications, 40(7), 2410-2420.

17. Zhao, X. (2008, November). A study of performance evaluation of HRM: based on data mining. In 2008 International Seminar on Future Information Technology and Management Engineering (pp. 45-48). IEEE.

18. Bissola, R., \& Imperatori, B. (2014). The unexpected side of relational e-HRM: Developing trust in the HR department. Employee Relations, 36(4), 376-397.

19. Platanou, K., \& Mäkelä, K. (2016). HR function at the crossroads of digital disruption. Työn1/2016.

20. Ross, P., \& Blumenstein, M. (2013). Cloud computing: the nexus of strategy and technology. Journal of Business Strategy, 34(4), 39-47.

21. Davis, F. D. (1985). A technology acceptance model for empirically testing new end-user information systems: Theory and results (Doctoral dissertation, Massachusetts Institute of Technology).

22. Lee, H., Zhang, Y., \& Chen, K. L. (2013). An investigation of features and security in mobile banking strategy. Journal of International Technology and Information Management, 22(4), 2.

23. Gefen, D., Karahanna, E., \& Straub, D. W. (2003). Trust and TAM in online shopping: an integrated model. MIS quarterly, 27(1), 51-90.

24. Conkin, J. H., Gotterer, M.H. \& Rickman, J. (1982). Online terminal response time: The effects of background activity. Information and Management, 5 (3), 169-173.

25. Panayotopoulou, L., Vakola, M., \& Galanaki, E. (2007). E-HR adoption and the role of HRM: evidence from Greece. Personnel Review, 36(2), 277-294.

\section{AUTHORS PROFILE}

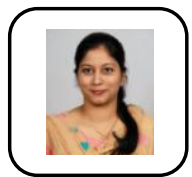

Richa Priya has 5 years in teaching and research experience in the domain of SAP and statistics. She also has an industry experience of about 3 years in ERP and software development. She has completed her MBA (Human Resource) from the Savitribai Phule Pune University. Currently she is perusing her $\mathrm{PhD}$ from Symbiosis International (Deemed University). She has published a research paper in ABDC B Journal. Her research interest is digitization in HR, Data Mining, and Artificial Intelligence.

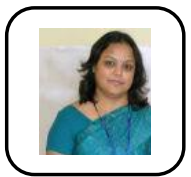

Vinita Sinha is Associate Professor and HOD Human Resource at Symbiosis center

for management and human resource development Her core area is Organizational Behavior. She has over 14 years of experience in teaching. She has completed her PhD from Purvanchal University (U.P.), She has published several research papers in both national and International Journals of repute and presented papers in prestigious conferences. 